\title{
INSCRIÇÃO PARA 1978
}

(Se ainda não pagou a sua quota para 1978 é favor preencher o talão abaixo indicado e enviā-lo com a maior brevidade para o Secretariado da S.P.Q., Av. da República,37,40,Lisboa)

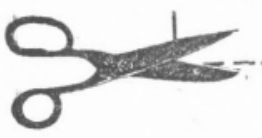

Ao Secretariado da Sociedade Portuguesa de Química, Junto envio o cheque / ordom postal n? sobre o Banco

para pagamento da minha inscrição, par 1978, como membro da Sociedade Portuguesa de Química.

Data, / / Assinatura:

Nome:

Morada:

Endereço Profissional: 
S Ã 0

HORAS..

de pagar

a sua

bOTA!

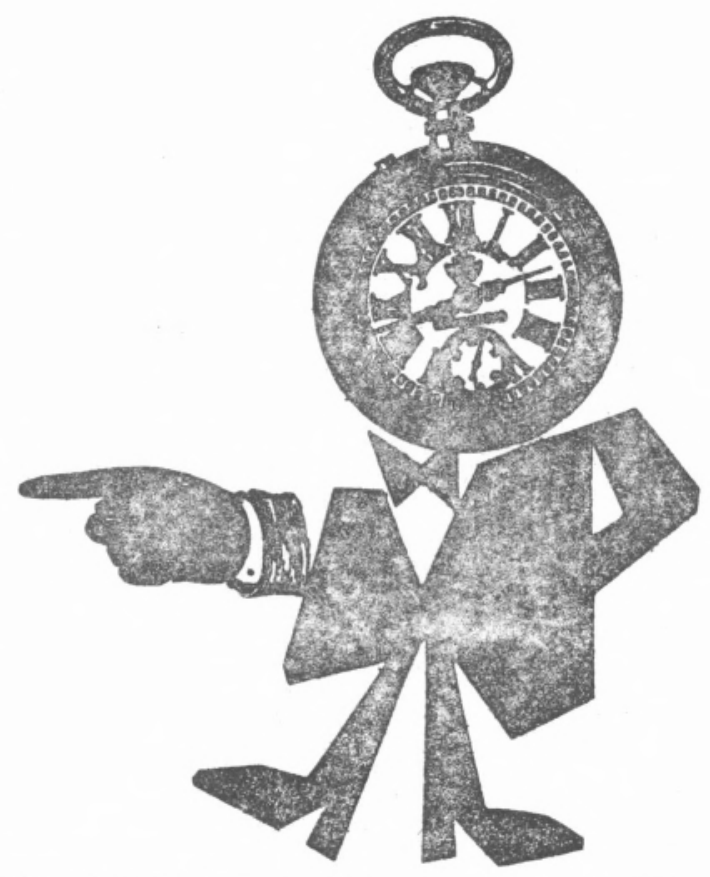

